УДК 372.881 .111 .1

DOI: 10.17277/voprosy.2017.04.pp.167-172

\title{
THE DISCURSIVE APPROACH TO DEVELOPING TESTS FOR ESP ASSESSMENT IN HIGHER EDUCATIONAL INSTITUTIONS
}

\author{
L. Yu. Korolyova
}

Tambov State Technical University, Tambov, Russia

Reviewed by Doctor of Pedagogic Sciences, Professor R. P. Milrood

Keywords: assessment tools and resources; competence; discursive approach; ESP assessment system; higher educational institution; language skills; paper-and-pencil tests.

\begin{abstract}
The problem of assessing English for specific purposes (ESP) in higher educational institutions is focused on. The dependence of ESP assessment system on the development of competences on the whole and language competences in particular as one of the requirements of educational standards is paid attention to. The classification of ESP assessment tools and resources is given and paper-and-pencil tests are featured as the most widespread type of continuous assessment of ESP in Russian higher educational institutions. The term 'discourse' is interpreted as well as the discursive approach and its components. The discursive approach to developing paper-and-pencil tests is discussed. The advantages of such tests over conventional tests are analyzed on the base of examples.
\end{abstract}

\section{Introduction}

The modern education system focuses on teaching foreign languages in such a way that they could be used in various professional fields. From this angle English for specific purposes (ESP) represents an interesting research object as it is the most popular foreign language learned in all Russian educational institutions including institutions of higher professional education. Different approaches are applied to both teaching ESP and evaluating it. The system of assessing ESP learners' knowledge is changing constantly according to educational standards and requirements of the time.

It should be noted that contemporary educational standards are based on the development of competences. Therefore language teachers must take into

Королева Людмила Юрьевна - кандидат филологических наук, доцент кафедры «Международная профессиональная и научная коммуникация», e-mail: lyu-korolyva@yandex.ru, ТамбГТУ, г. Тамбов, Россия.

УНИВЕРСИТЕТ им. В.И. ВЕРНАДСКОГО. №4(66). 2017. 
account numerous components covering language aspects and competences. And the foreign language assessment system must also reflect these tendencies.

Let us consider competences which University students must have as a result of their study. Firstly, we will turn to the term 'competence'. It is interpreted as "a combination of particular knowledge, abilities and skills which a person must have together with the practical work experience" [1]. The number of competences a student must get varies depending on his major. But they are divided into general competences and professional ones. The first type refers to general knowledge, abilities and skills needed in many spheres. The second type covers those skills, abilities etc., which are demanded in the particular professional field and are directly connected with a student's future job. As for general competences they include the following ones:

- a social competence (an ability to take responsibility, to brainstorm ideas and make decisions appropriate for all members of the team a person is working in, to have tolerance to different ethnocultures and religions, to combine personal interests with needs of the enterprise);

- a cognitive competence (readiness to improve one's educational level, a need to realize personal potential, an ability to acquire new knowledge by selfeducation, self-development);

- a communicative competence (the knowledge of the ways which help to communicate in different languages orally or in the written form, including computer programming);

- a socio-information competence (the knowledge of information technologies and a critical attitude to social information presented by mass media);

- crosscultural competences;

- a special competence (readiness to evaluate professional acts independently) [2].

In fact, all these competences can be formed in the language educational process but, in my opinion, the dominant competence should be a communicative one whereas all the rest are subordinate to it developing as a result of it. It is explained by the peculiarities of the language teaching process when a teacher pays attention first of all to those methods which can help students to understand the basic principles of this or that language and encourage them to communicate using the language they are studying. If they have achieved this goal and acquired skills in all four types of the communicative activity, i.e. reading, writing, speaking and listening, it is possible to develop all other competences on the base of these language skills. Consequently, students will be able to discuss different ideas, express their points of view, make decisions etc. in a foreign language.

So the foreign language assessment system must focus on the evaluation of the development of the above mentioned competences. Let us consider those tools and resources that can be used for these purposes. They can be divided into four categories:

- performance (debates, written reports, experiments, speeches, projects); tests);

- paper-and-pencil tests (standardized tests, end-of-unit tests, teacher-made

- personal communication (individual conferences, small-group discussions, interviews); 
- observation and perceptions (classroom interaction, student involvement) [3].

We would like to focus on paper-and-pencil tests as the most widespread type of continuous assessment of ESP in Russian higher educational institutions. This can be explained by the fact that teachers try to develop their own tests relying on individual groups, their level of English and specific purposes for which students must learn English. To comply with educational standards and evaluate students' competences as well as their language skills developed at some level these tests must be based on the discursive approach.

\section{Discourse and its functions in Linguistics}

The problem of discourse became important in Linguistics in the second half of the XX century. The term 'discourse' is defined as "a textual unity covering extralinguistic factors - pragmatic, socio-cultural, psychological and others; speech examined as a purposeful social act, as a component peculiar for people's relationships and mechanisms of their consciousness" [4]. On the one hand, discourse is connected with a pragmatic situation which is necessary for the determination of the discourse and its communicative adequacy; on the other hand discourse is connected with "mental acts of interlocutors: ethnographic, psychological and socio-cultural rules and strategies of producing and interpreting speech in different conditions" [4].

So the discursive approach to making tests must cover many factors related to specific conditions in which a person can occur and behave accordingly expressing his feelings and emotions. The approach has three aspects: contextual, cohesive and coherent. All of them are interrelated.

The contextual aspect of the discursive approach allows to develop such tests which include textual units and help learners to understand which variant from the suggested ones is the best according to the context.

The cohesive aspect deals with the correlation of words in the context and provides students with an opportunity to understand this correlation in this particular textual unit.

The coherent aspect of the discursive approach is based on the connection of the central idea of the discourse with other parts.

\section{The discursive approach to developing tests}

Traditional tests usually deal with Grammar and Vocabulary. Therefore doing such tests students must prove the development of specific skills in using particular Grammar and Vocabulary learned as a result of studying some topic. The discursive approach helps make such a test that will be connected with both Grammar and Vocabulary and textual units as a part of the discourse studied at some period. In case of learning English for specific purposes tests based on the discursive approach are connected with real life situations (professional areas) more and consequently play the function of not only assessment tools but also instruments for developing a communicative competence. 
To compare different types of ESP tests let us consider the course "International professional communication" taken as a part of the Master's program "Civil Engineering" at Tambov State Technical University where English is not a major and it is learned for specific purposes, i.e. for the ability to use it in the professional field. The course is taken in the first term and learners are expected to earn three credits doing 108 hours. The course is divided into three modules which cover such areas as "Professional communication in English", "Scientific communication in English" and "Business communication in English".

At the end of every module students must write an end-of-unit test. In case it is a traditional test it can consist of the following tasks:

- put the appropriate words into the sentences (e.g. In the modern world these professions __ high technical skills; a) require; b) employ; c) promote);

- use prepositions in the sentences (e.g. He is confident designing projects; a) of; b) in; c) on);

- choose the appropriate modal verb (e.g. The new joystick remotely control gears and steering mechanism of the mobile robot; a) can; b) should; c) mustn't);

- use one of the adjectives in the sentences (e.g. It has a point that writes on the paper; a) cubic; b) triangular; c) square);

- complete the sentences with the appropriate tense (e.g. This robot (work) only in a large space).

These tasks focus on the evaluation of students' knowledge of specific Grammar (in this case it relates to the use of modal verbs and verb tenses) and Vocabulary (the words refer to the topic "Professional Communication" and are used to describe different professions, requirements in some professional fields etc. and prepositions which are peculiar for these words).

If the discursive approach is used in the test, the latter can include such tasks as:

- complete the story with the corresponding form of the word in brackets (e.g. The translucent properties of this ceramic (1) (first/discover) by

Table 1

\section{The product design specification}

\begin{tabular}{|c|c|}
\hline Description & $\begin{array}{l}\text { A kitchen appliance that heats and cooks food by exposing it to } \\
\text { electromagnetic radiation }\end{array}$ \\
\hline Performance & Quick and efficient food heating \\
\hline Ergonomics & $\begin{array}{l}\text { * A dial-type timer. } \\
* \text { A digital control panel for operation (liquid crystal or vacuum } \\
\text { fluorescent display, numeric buttons for entering the cook time, a power } \\
\text { level selection feature) }\end{array}$ \\
\hline Dimensions & $50 \times 30 \times 35 \mathrm{~cm}$ \\
\hline Weight & $10,5 \mathrm{~kg}$ \\
\hline Safety & One should be cautious while operating it \\
\hline
\end{tabular}


NASA ceramic engineers. They (2)___ (carry out) research to (3)__ (develop) tough new materials when they suddenly NASA ceramic engineers. They (2) ___ (carry out) research to (3)___ (develop) tough new materials when they suddenly (4)___ (notice) that light (5)____ (pass) through one of the ceramics. Now, however, the ceramic (6)____ (commonly utilise) by dental engineers for (7)___ (make) protective braces, or restraints, for children's teeth.);

- read the following product design specification and write what product is described, e.g. (Table 1):

- put the paragraphs of the covering letter in the right order;

- put the headings of the $C V$ in the right order.

In all the tasks contextual, cohesive and coherent aspects of the discursive approach help students to choose the best answer relying on the given professional context.

\section{Conclusion}

To sum up, if we compare traditional tests and tests based on the discursive approach, we can say that the former fulfill the role of assessment tools but partially unlike tests of the second type that are aimed at the evaluation of the communicative competence development. However the combination of these tests will result in the perfect assessment instrument able to encourage learners to demonstrate their language skills and competences.

\section{References}

1. http://www.eidos.ru/journal/2005/0910-12.htm (accessed November 10, 2014).

2. http://www.na-journal.ru/4-2013-gumanitarnye-nauki/374-formirovaniekljuchevyh-kompetencij-v-obrazovanii (accessed November 14, 2014).

3. http://www.edu.gov.mb.ca (accessed January 26, 2017).

4. Yartsev V. N. [Ed.] Lingvisticheskii entsiklopedicheskii slovar' [Linguistic encyclopaedic dictionary], Moscow: Sovetskaya entsiklopedia, 1990, 685 p. (In Russ.)

\section{Список литературы}

1. Бермус, А. Г. Проблемы и перспективы реализации компетентностного подхода в образовании [Электронный ресурс] / А. Г. Бермус // Интернет-журнал «Эйдос». - Режим доступа : http://www.eidos.ru/journal/2005/0910-12.htm (дата обращения: 10.11.2014).

2. Аргунова, П. Г. Формирование основных компетенций в образовании [Электронный ресурс] / П. Г. Аргунова // Научно-издательский центр «Аспект». Режим доступа : http://www.na-journal.ru/4-2013-gumanitarnye-nauki/374-formirova nie-kljuchevyh-kompetencij-v-obrazovanii (дата обращения: 14.11.2014).

3. Classroom assessment [Электронный pecypc]. - Режим доступа : http://www.edu.gov.mb.ca (дата обращения: 26.01.2017).

4. Лингвистический энциклопедический словарь / под ред. В.Н.Ярцева. М. : Советская энциклопедия, 1990. - 685 с. 


\section{Дискурсивный подход к разработке тестов при оценивании английского для специальных целей в высших учебных заведениях}

\section{Л. Ю. Королева}

ФГБОУ ВО «Тамбовский государственный технический университет», г. Тамбов, Россия

Ключевые слова: высшее учебное заведение; дискурсивный подход; компетенция; оценивание английского для специальных целей; оценочные инструменты и ресурсы; письменный тест; языковые навыки.

Аннотация: Рассмотрена проблема оценивания английского для специальных целей в высших учебных заведениях. Прослежена связь системы оценивания английского для специальных целей с формированием компетенций в целом и языковых компетенций, в частности, что является одним из требований образовательных стандартов. Дана классификация оценочных инструментов и ресурсов, среди которых автор выделяет письменные тестовые задания как наиболее распространенный способ текущего оценивания английского для специальных целей в российских вузах. Даны интерпретации понятий «дискурс» и «дискурсивный подход». Выделены составляющие компоненты последнего. Проанализирован дискурсивный подход к разработке письменных тестов. В результате рассмотрения конкретных примеров тестовых заданий, сделан вывод о преимуществах тестов, составленных с учетом дискурсивного подхода, над традиционными тестовыми заданиями.

(С) Л. Ю. Королева, 2017 